\title{
Modeling the development of maps of complex cells
} Jan Antolik* and James A Bednar

\author{
Address: Institute for Adaptive and Neural Computation, University of Edinburgh, Edinburgh, EH1 2QL, UK \\ Email: Jan Antolik* - j.antolik@inf.ed.ac.uk \\ * Corresponding author
}

from Seventeenth Annual Computational Neuroscience Meeting: CNS*2008

Portland, OR, USA. 19-24 July 2008

Published: II July 2008

BMC Neuroscience 2008, 9(Suppl I):P96 doi:10.1 I86/I47I-2202-9-SI-P96

This abstract is available from: http://www.biomedcentral.com/I47I-2202/9/SI/P96

(c) 2008 Antolik and Bednar; licensee BioMed Central Ltd.

Hubel \& Wiesel [1] classified primary visual cortex (V1) neurons as either simple, with responses strongly modulated by the spatial phase of a sine grating, or complex, i.e. largely phase invariant. Much progress has been made in understanding how simple cells develop, and there are now detailed computational models establishing how they can form topographic maps ordered by orientation preference. There are also models of how individual complex cells can develop using outputs from simple cells with different phase preferences, but no model of how a realistic topographic orientation map of complex cells could be formed based on the actual connectivity patterns found in V1. Addressing this question is important, because existing simple-cell models produce maps that group similar spatial phases together, which is contrary to experimental evidence, and makes it difficult to construct complex cells. Overcoming this limitation is not trivial, because the simple-cell models are driven by correlations in the input, and phase is more highly correlated than orientation in natural images.

In this work, we model V1 as two topographically organized sheets, one representing cortical layer 4C (V1Simple) and one representing layer 2/3 (V1Complex). Layer 4C receives direct thalamic input via connection fields with jittered retinotopic coordinates (figure 1). Both sheets are connected with narrow feed-forward and feedback connectivity. Only layer $2 / 3$ contains long range lateral connectivity, in line with current anatomical findings. Initially all weights in the model are random, and each is modified via a Hebbian learning rule. The model develops smooth, matching, realistic orientation preference maps in both sheets. Layer 4 units become simple cells, with phase preference arranged randomly, while those in

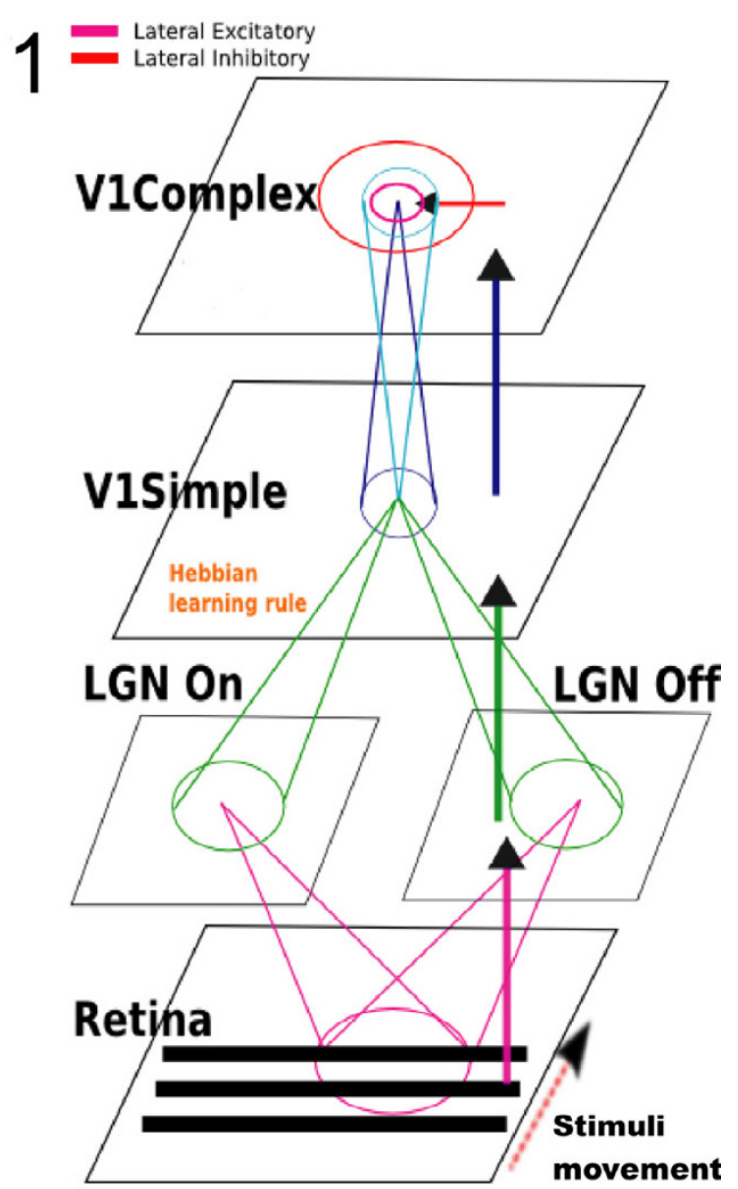

Figure I

Topographical connectivity in the model. 


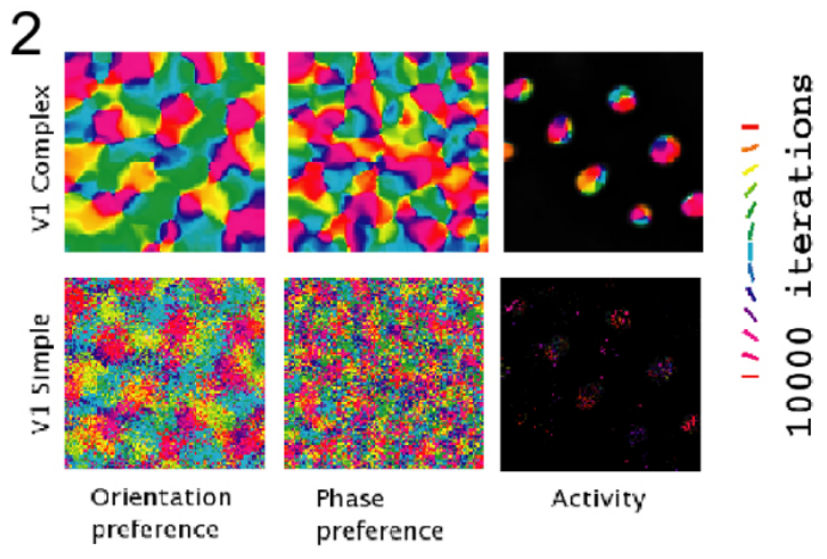

\section{Figure 2}

Orientation preference maps.

layer 2/3 are primarily complex cells (figure 2). To our knowledge this model is the first explaining how simple cells can develop with random phase preference, and how smoothly organized maps of complex cells can develop, using realistic patterns of connectivity.

\section{Acknowledgements}

This work has been carried out using the new Topographica simulator available freely from http://www.topographica.org. This project is funded by the Engineering and Physical Sciences Research Council and the Medical Research Council UK through Edinburgh University Neuroinformatics Doctoral Training Centre. Thanks to: Chris Ball, Judith S. Law and Chris Palmer

\section{References}

I. Hubel DH, Wiesel TN: Receptive fields and functional architecture of monkey striate cortex. Journal of Neuroscience 1968, 195:215-243.
Publish with Biomed Central and every scientist can read your work free of charge

"BioMed Central will be the most significant development for disseminating the results of biomedical research in our lifetime. "

Sir Paul Nurse, Cancer Research UK

Your research papers will be:

- available free of charge to the entire biomedical community

- peer reviewed and published immediately upon acceptance

- cited in PubMed and archived on PubMed Central

- yours - you keep the copyright
BioMedcentral 